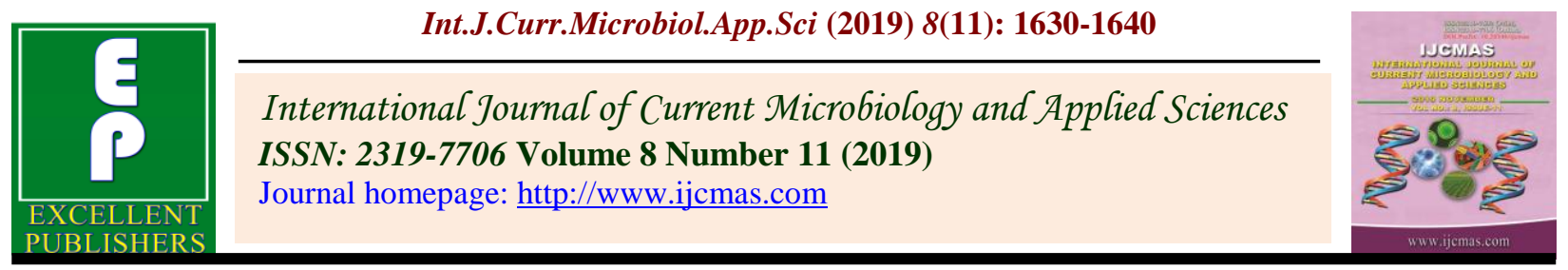

Original Research Article

https://doi.org/10.20546/ijcmas.2019.811.188

\title{
Performance of Wheat Genotypes under Late Sown Heat Stress Condition
}

\author{
Minakshi R. Neware*, D.V. Durge and N.R. Potdukhe \\ Department of Agriculture Botany, Dr. PDKV, Akola (M.S.)-444104, India \\ *Corresponding author
}

\section{Keywords}

Wheat, Late sown irrigated condition, Heat tolerance, Correlation with yield

\section{Article Info}

Accepted:

12 October 2019

Available Online:

10 November 2019

\section{A B S T R A C T}

A field experiment was conducted in research farm of Wheat Research Unit, Dr. PDKV, Akola (M.S.), during rabi season of 2016-17 and 2017-18 with 9 wheat genotypes viz., AKAW 5023, AKAW 4927, PBN 4905, PBN 4751-02, NIAW 3523, NIAW 2891, AKAW 4210-6 (C), NIAW 34 (C), NIAW 1994 (C) and sown on late (December 1-10) irrigated condition in a randomized block design with three replications to evaluate the performance of these genotypes under late sown (irrigated) heat stress condition to find out the suitable heat tolerance genotypes for Vidharbha condition. Under late sown conditions yield attributes, spike length $(\mathrm{cm})$, no. of grains/spike, rate of grain filling $\left(\mathrm{mg} \mathrm{m}^{-2} \mathrm{GDD}^{-1}\right)$, grain growth duration (days), 1000 grain weight $(\mathrm{g})$, grain yield/ha (q) and harvest index (\%) were observed. On pooled basis significantly higher yield recorded by genotype NIAW 2891 followed by NIAW 3523 over best check AKAW 4210-6 and other genotypes during both the year of sowing and noted as heat tolerance genotypes. Rate of grain filling $(0.987 * *), 1000$ grains weight $(0.762 * *)$ and harvest index $(0.719 * *)$ showed positive and significant correlation with grain yield.

\section{Introduction}

Wheat (Triticum aestivum L.) is an important cereal crop ranking number one globally. During 2017-18 in India, it occupied an area of 297.67 Lakh ha with total production of 96 Lakh Tons and productivity of $31.19 \mathrm{q} / \mathrm{ha}$. In Maharashtra state, it occupied 12.72 lakh ha area with total production of 22.14 lakh tons and productivity was $17.40 \mathrm{q} / \mathrm{ha}$. In Vidarbha, area under wheat crop was 4.72 lakh ha with production of 7.31 lakh Tons and productivity is $15.59 \mathrm{q} / \mathrm{ha}$ (Anonymous, 2018). Late planting of wheat is one of the major reasons for yield reduction, since about $60 \%$ of the wheat crop is cultivated at late sowing conditions after harvesting the transplanted aman rice (Badruddin et al., 1994). High temperature $\left(>30^{\circ} \mathrm{C}\right)$ at the time of grain filling is one of the major constraints in increasing productivity of wheat in tropical countries like India. It has been reported that 
single grain mass falls by $3 \%-5 \%$ for every $1{ }^{\circ} \mathrm{C}$ rise in temperature above $18^{\circ} \mathrm{C}$. About $50 \%$ of wheat area is planted after the optimum time and therefore, suffers heat stress which causes a significant yield loss.

In India, late planting of wheat exposes it to high temperature at reproductive stage causing reduction of the number of kernels per spike (Al-Khatib and Paulsen, 1990, Bhatta et al., 1994, He and Rajaram, 1993 and Islam et al., 1993) and the size (Acevedo et al., 1991 and Asana and Saini AD, 1962). The net effect of these is the reduced grain yield. However, this problem will be further aggravated due to global warming, because in India the annual mean temperature of $25.75^{\circ} \mathrm{C}$ will rise by about $0.21^{\circ} \mathrm{C}$ and $0.39^{\circ} \mathrm{C}$ by 2050 and 2100 , respectively (Karmakar and Shrestha, 2000). In spite of low yield of wheat due to post anthesis heat stress, cultivation of wheat cannot be avoided totally. Thus, the irrigation dependent Boro rice cultivation may need to be replaced in future by partially irrigated or non irrigated wheat cultivation to reduce the use of underground water. Therefore, efforts ought to be made to minimize the late sown yield reduction by screening or developing high temperature tolerant wheat genotypes/ varieties.

\section{Materials and Methods}

The study was carried out during 2016-17 and 2017-18 wheat season in the research field of Wheat Research Unit, Dr. Panjabrao Deshmukh Krishi Vidhyapeeth, Akola (M.S).

Akola is situated in the subtropical zone at the latitude of $20042^{\prime}$ North and longitude of 770 02' East. Altitude of the place is $307.41 \mathrm{~m}$ above the mean sea level. Treatments were 9 wheat genotypes (AKAW 5023, AKAW 4927, PBN 4905, PBN 4751-02, NIAW 3523, NIAW 2891, AKAW 4210-6 (C), NIAW 34 (C), NIAW 1994 (C) sown on late (December
1-10) condition in randomized block design with three replications. For late-sown conditions, management and inputs were same except the seeding date. Each unit plot size was Gross $-6.0 \mathrm{~m} \times 2.16 \mathrm{~m}$ (12 rows) and net plot size $6.0 \mathrm{~m} \times 1.80 \mathrm{~m}$ (10 Middle rows) length of each. Seeds were sown continuously in $18 \mathrm{~cm}$ apart rows at a seed rate of $125 \mathrm{~kg}$ ha-1. Recommended fertilizer doses 90:60:40 NPK kg ha ${ }^{-1}$ respectively was applied. Half $\mathrm{N}$ and a complete dose of $\mathrm{P}_{2} \mathrm{O}_{5}$ and $\mathrm{K}_{2} \mathrm{O}$ were given as a basal dose at sowing while the remaining $\mathrm{N}$ was applied at 18 days after sowing.

A uniform pre-sowing soaking irrigation was given to all the plots during both the experiments. In all, the crop received seven to eight need based irrigations at different critical growth stages. Intercultural operations were done properly as per WRC recommendation and when necessary. Rate of grain filling was calculated by following formulas given by Chinnusamy and Renu Khanna Chopra, 2009.

$$
\begin{aligned}
& \begin{array}{l}
\text { Rate of grain filling } \\
\left(\mathrm{mg} \mathrm{m}^{-2} \mathrm{GDD}^{-1}\right)
\end{array} \\
& \text { Grain yield } \mathrm{m}^{-2} \\
& \text { = -------- } \\
& \text { GDD from the } 50 \% \text { anthesis } \\
& \text { to Maturity }
\end{aligned}
$$

The total number of days from 50 per cent anthesis till the day of maturity were counted in each plot and expressed as grain growth duration (days). Harvest index (HI) was calculated by using the formula of Donald (1962).

$$
\begin{aligned}
& \text { Harvest index } \\
& \qquad \text { Grain yield }\left(\mathrm{kg} \mathrm{plot}^{-1}\right) \\
& \text { = ---------------- x } 100 \\
& \text { Biological yield } \\
& \quad(\text { grain }+ \text { Straw })\left(\mathrm{kg} \mathrm{plot}^{-1}\right)
\end{aligned}
$$

Statistical analysis was done by employing standard statistical methods for randomized 
block design as suggested by Panse and Sukhatme (1967) and correlation analysis was done as per the formula suggested by Karl Pearson's correlation coefficient.

\section{Results and Discussion}

\section{Spike length $(\mathrm{cm})$}

Pooled data for spike length, the best check NIAW $1994(11.5 \mathrm{~cm})$ was statically comparable with genotypes, AKAW 5023 $(11.32 \mathrm{~cm})$ and PBN $4905(11.27 \mathrm{~cm})$ were found at par with superior check NIAW 1994. Remaining genotypes, NIAW 2891 (10.61 $\mathrm{cm})$, AKAW 4927 (10.48 cm), NIAW 3523 $(10.06 \mathrm{~cm})$ and PBN 4751-02 (8.45 cm) statically noted lowest spike length when compared with best check and other genotypes under study (Fig. 1).

Gill et al., (2013) and Kumar et al., (2015) also reported similar results indicating a decrease in spike length under late sown condition than timely and found genotypic differences also. Kumar et al., (2016) revealed that, reduction of spike length about 12.57$31.33 \%$ in heat stress environment as compared to control condition.

\section{Number of grains spike $\mathrm{e}^{-1}$}

From the pooled data, among the genotypes under study PBN 4905 (53.33) found statistically at par with superior check NIAW 34 (51.40). While, genotypes AKAW 4927 (45.43), NIAW 2891 (44.76), NIAW 3523 (43.36), AKAW 5023 (42.40) and PBN 475102 (39.83) statistically recorded minimum number of grains spike ${ }^{-1}$. Reduction percent was $2.41 \%$ in second year as compared to first year. Modheja et al., (2008) said that the terminal or late heat stress during the last phases of wheat development especially from booting, heading, anthesis and grain filling stages of the spring wheat cultivars is considered as one of the major environmental constraints that drastically reduces grain number spike $^{-1}$ and grain weight and consequently significant reduction in wheat grain yield throughout most of the wheat (Fig. 2).

\section{Rate of grain filling}

Pooled data was statistically significant in heat stress condition. It indicated that NIAW 2891 (145.45) recorded significantly highest rate of grain filling followed by NIAW 3523 (136.25) over best check genotype AKAW 4210-6 (118.95). While, genotype AKAW 5023 (127.90) and PBN 4751-02 (114.34) found at par with superior check AKAW 4210-6 and the lowest rate of grain filling were recorded in PBN 4905 (90.96) followed by AKAW 4927 (111.67). In this investigation, the data revealed from general mean rate of grain filling were reduced by $1.17 \%$ during second season i.e. rabi 2017-18 over first season i.e. 2016-17 in heat stress condition. Sayed and Gadallah (1983) reported that longer grain filling period would increase the availability of photo assimilates leading to higher grain yield, but high temperature during the grain filling period of wheat impose limitations on kernel weight and grain yield through reduction of grain filling duration (Fig. 3).

\section{Grain growth duration (days)}

The pooled mean data revealed that in present investigation among the wheat genotypes tested, genotype PBN 4905 (41.83 days) taken significantly maximum days to grain growth followed by AKAW 4927 (41.33), AKAW 5023 (39.66), NIAW 3523 (39.16) and PBN 4751-02 (38.50) and also found at par with best check AKAW 4210-6 (41.50). Among all genotypes, significantly minimum duration for grain growth taken by genotype NIAW 2891 (33.50 days) in heat stress condition. The rate of grain growth increases as temperature 
increases, but this apparently depends on whether the number of grains per spike is reduced (Sofield et al., 1977). Vishwanathan and Khanna-Chopra (2001) showed that both duration and rate of grain growth were reduced by heat stress in genotypes differing in grain weight stability (Fig. 4).

\section{0 grain weight $(g)$}

The pooled mean data revealed that in present investigation among the wheat genotypes tested, genotype NIAW 2891 (56.79 g) and NIAW 3523 (48.37 g) recorded significantly highest mean test weigh over a best check AKAW 4210-6 (43.61 g) and rest of the genotypes under studied (Fig. 5). However, genotypes AKAW 5023 (44.83 g), PBN 745102 (42.12 g) and AKAW 4927 (39.14 g) were found statistically at par with best check AKAW 4210-6. Among the genotypes, significantly lowest test weigh was recorded in PBN 4905 (39.14 g) in heat stress condition. Genotype NIAW 2891 and NIAW 3523 recorded significantly higher 1000 grain weight (56.79 and $48.37 \mathrm{~g}$, respectively) as compared to rest of the genotypes. This might be due to the higher ability to utilize the available resources during vegetative period which results the higher yield attributes under stress condition.

\section{Grain weight plant ${ }^{-1}(\mathrm{~g})$}

The pooled mean data revealed that in present investigation among wheat genotypes tested, top ranking genotype NIAW 2891 recorded significantly highest mean grain weight plant $^{-1}$ of 5.59 g over a best check AKAW 4210-6 $(4.36 \mathrm{~g})$ and rest of the genotypes under studied. However, genotypes NIAW 3523 (5.05 g), AKAW 5023 (4.58 g), PBN 4751-02 (4.05 g) and AKAW 4927 (3.77 g) were found statistically at par with best check AKAW 4210-6. Among the genotypes, significantly lowest grain weight plant $^{-1}$ was recorded in PBN 4905 (3.20 g) in heat stress condition. Grain weight mainly depends upon the capacity of leaves, stem and spikelets to synthesize the food material and translocate it onward grain development. Some wheat genotypes showed decreasing trend in grain weight plant $^{-1}$ under late sown condition (terminal high temperature stress). It might be due to reduction in grain number spike ${ }^{-1}$ as well shriveled grain because of competition for assimilate between grains of the same ear has been much prominent and they could not get sufficient assimilate as well as low leaf area, low photosynthesis and less relative water content (Fig. 6).

\section{Grain yield plot $^{-1}(\mathrm{~kg})$}

Significantly superior grain yield plot $^{-1}$ was recorded by genotype NIAW $2891(3.84 \mathrm{~kg})$ and NIAW 3523 (3.65 kg) when compared with best check AKAW 4210-6 (3.20 kg). Genotypes AKAW 5023 (3.39 kg), PBN 4751-02 (3.06 kg) and AKAW $4927(2.88 \mathrm{~kg})$ were remained at par with best check AKAW 4210-6. Among the genotypes, PBN 4905 $(2.42 \mathrm{~kg})$ recorded significantly lowest grain yield plot $^{-1}$ in heat stress condition of wheat. The reduction in grain yield plot $^{-1}(\mathrm{~kg})$ to the extent of $0.13 \%$ in rabi 2017-18 as compared with first year, might be due to higher temperature observed during different growth stage in second year which affected normal growth and development of crop and also affects dry matter production in different plants parts and its low translocation. Improvement in grain yield plot $^{-1}$ to the extent of $0.26 \%$ in NIAW 2891 over best check AKAW 4210-6 might be due to the higher ability of the genotype to utilize the available resources during vegetative period which resulted the higher yield attribute and due to more dry matter accumulation (Hulihalli et al., 2016) (Fig. 7). 
Table.1 Correlation study of yield parameters with yield of wheat under heat stress condition

\begin{tabular}{|c|c|c|c|c|c|c|c|c|c|}
\hline & $\begin{array}{c}\mathbf{5 0} \% \\
\text { flowering }\end{array}$ & $\begin{array}{c}\text { Days to } \\
\text { maturity }\end{array}$ & $\begin{array}{l}\text { Rate of } \\
\text { grain } \\
\text { filling }\end{array}$ & $\begin{array}{c}\text { Grain } \\
\text { growth } \\
\text { duration }\end{array}$ & $\begin{array}{l}\text { Spike } \\
\text { length }\end{array}$ & $\begin{array}{l}\text { No. of } \\
\text { grains } \\
\text { / spike }\end{array}$ & $\begin{array}{c}1000 \\
\text { grain } \\
\text { wt. }\end{array}$ & HI & $\begin{array}{l}\text { Yield } \\
\text { /ha }\end{array}$ \\
\hline $\begin{array}{c}50 \% \\
\text { flowering }\end{array}$ & 1 & 0.424 & -0.229 & -0.287 & 0.040 & -0.020 & -0.315 & -0.052 & -0.185 \\
\hline $\begin{array}{l}\text { Days to } \\
\text { maturity }\end{array}$ & & 1 & -0.411 & $0.709 * *$ & -0.059 & 0.147 & $-{ }^{-}$ & -0.067 & -0.412 \\
\hline $\begin{array}{l}\text { Rate of } \\
\text { grain } \\
\text { filling }\end{array}$ & & & 1 & -0.269 & -0.205 & -0.167 & $\begin{array}{c}0.753^{*} \\
*\end{array}$ & $\begin{array}{c}0.682^{*} \\
*\end{array}$ & $0.987^{* *}$ \\
\hline $\begin{array}{c}\text { Grain } \\
\text { growth } \\
\text { duration }\end{array}$ & & & & 1 & -0.040 & 0.150 & -0.348 & -0.061 & -0.306 \\
\hline $\begin{array}{l}\text { Spike } \\
\text { length }\end{array}$ & & & & & 1 & 0.254 & -0.104 & -0.260 & -0.219 \\
\hline $\begin{array}{l}\text { No. of } \\
\text { grains/ } \\
\text { spike }\end{array}$ & & & & & & 1 & -0.130 & -0.269 & -0.169 \\
\hline $\begin{array}{c}1000 \\
\text { grain wt. }\end{array}$ & & & & & & & 1 & 0.565 & $0.762 * *$ \\
\hline HI & & & & & & & & 1 & $0.682 * *$ \\
\hline Yield/ha & & & & & & & & & 1 \\
\hline
\end{tabular}

$*$ Significance at $5 \%, * *$ significance at $1 \%$

Fig.1 Effect of heat stress on spike length of wheat under heat stress condition

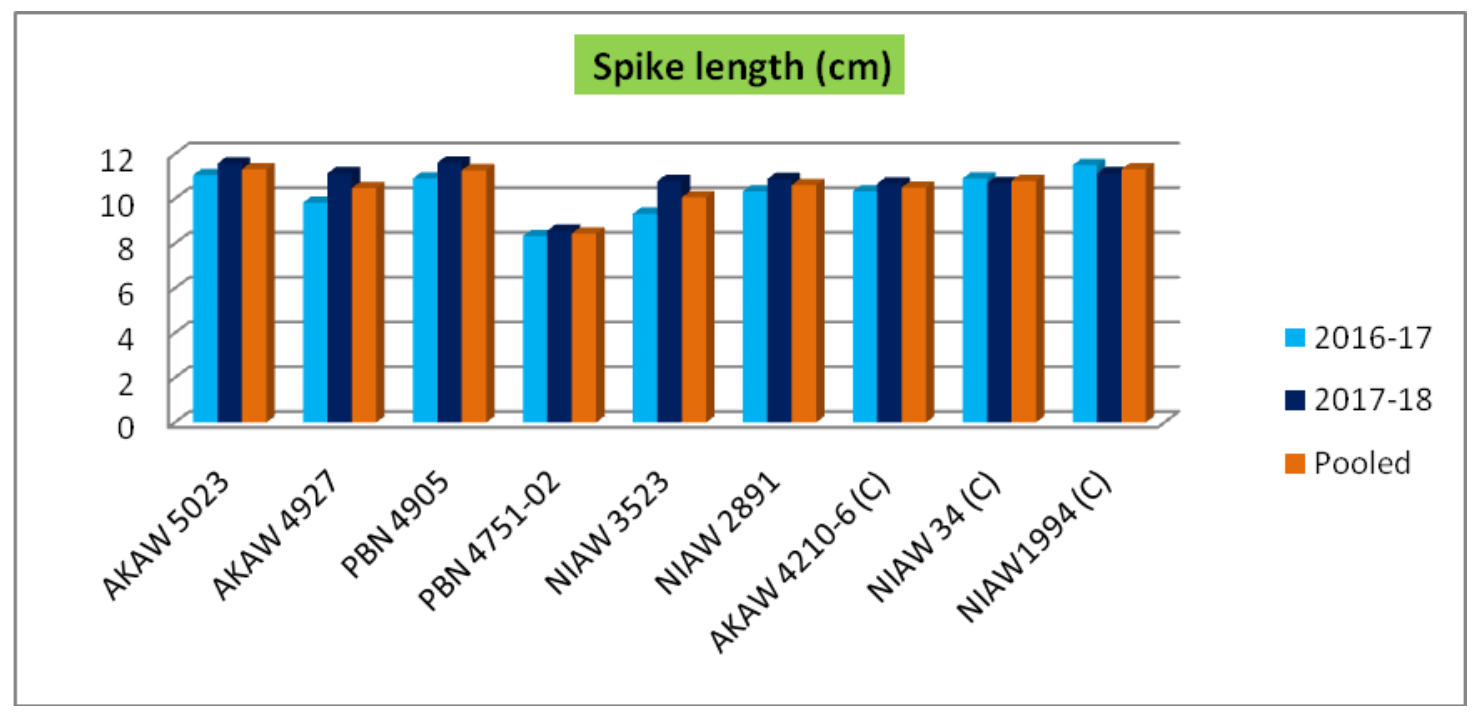


Fig.2 Effect of heat stress on no. of grains spike ${ }^{-1}$ of wheat under heat stress condition

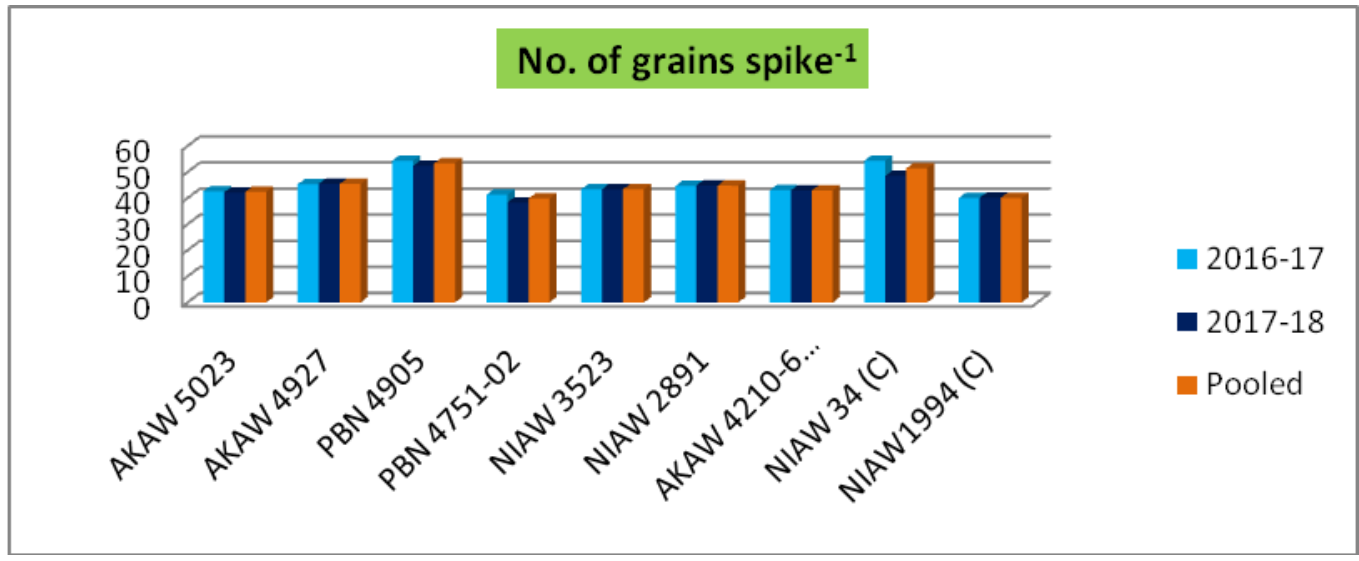

Fig.3 Effect of heat stress on rate of grain filling of wheat under heat stress condition

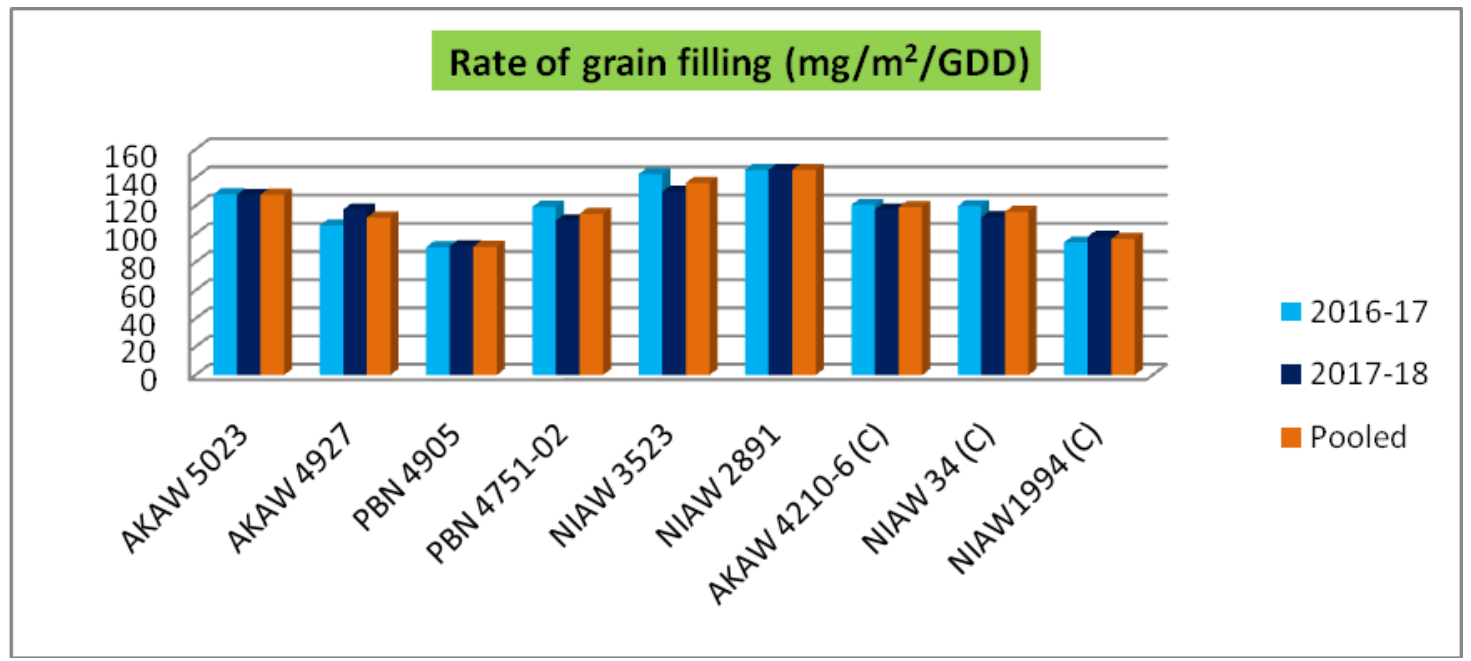

Fig.4 Effect of heat stress on grain growth duration of wheat under heat stress condition

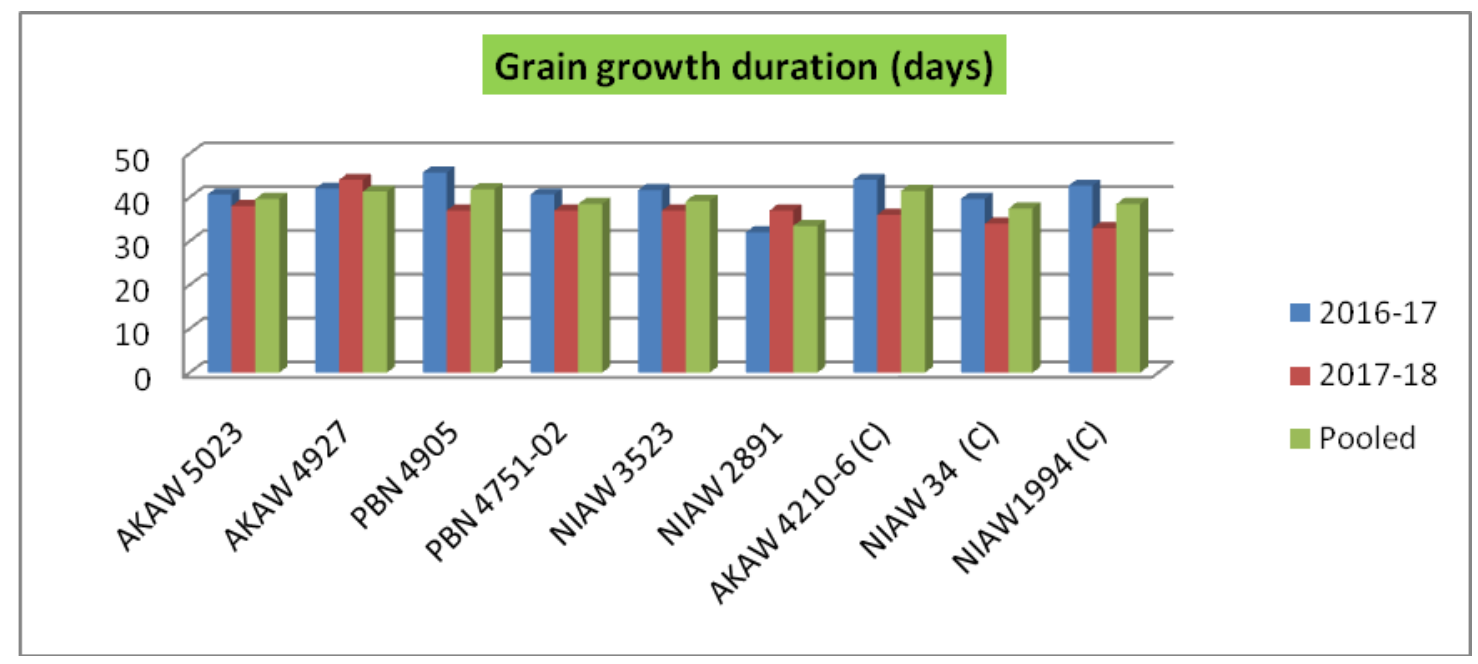


Fig.5 Effect of heat stress on 1000 grain weight of wheat under heat stress condition

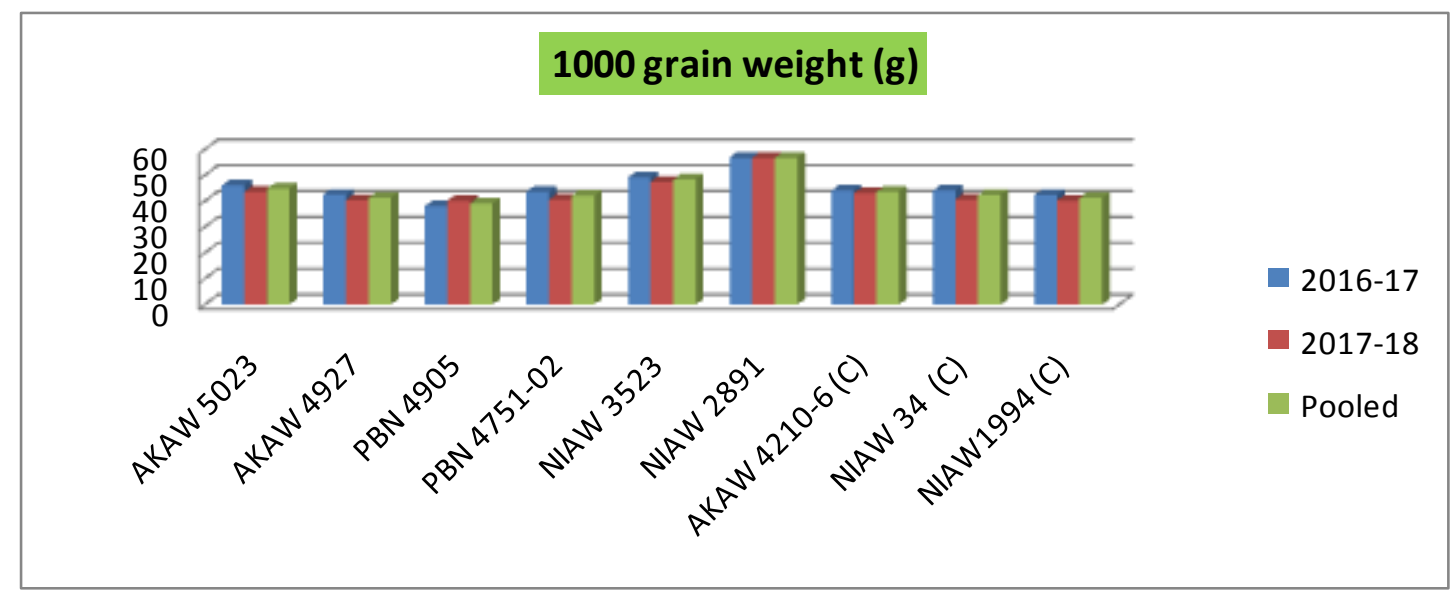

Fig.6 Effect of heat stress on grain yield plant ${ }^{-1}$ of wheat under heat stress condition

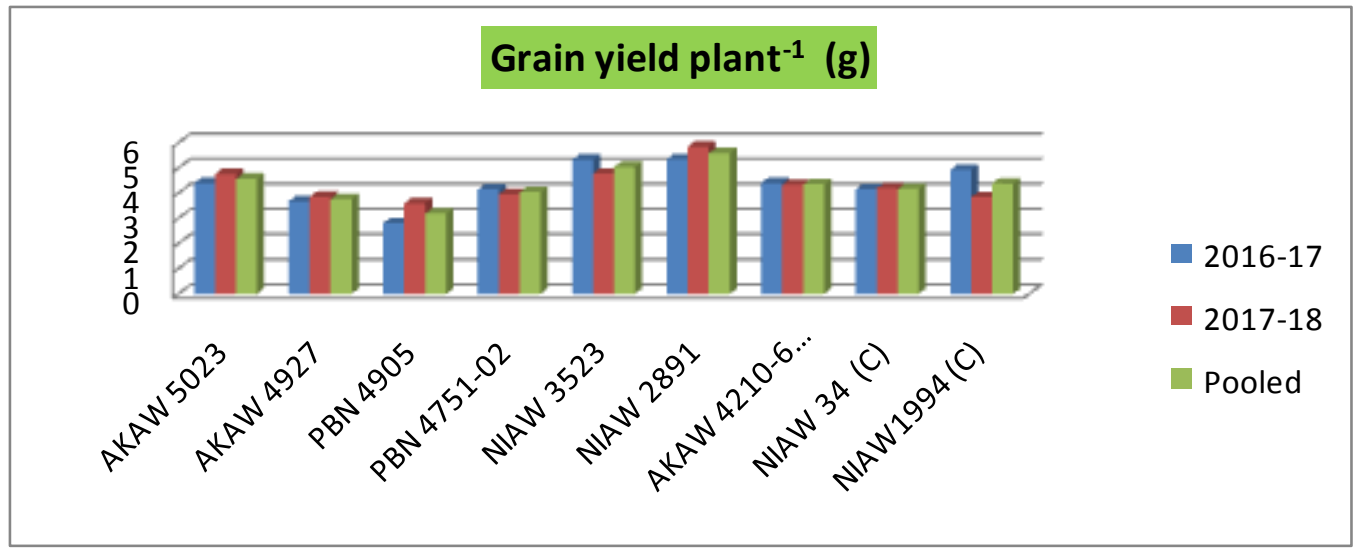

Fig.7 Effect of heat stress on grain yield plot $^{-1}$ of wheat under heat stress condition

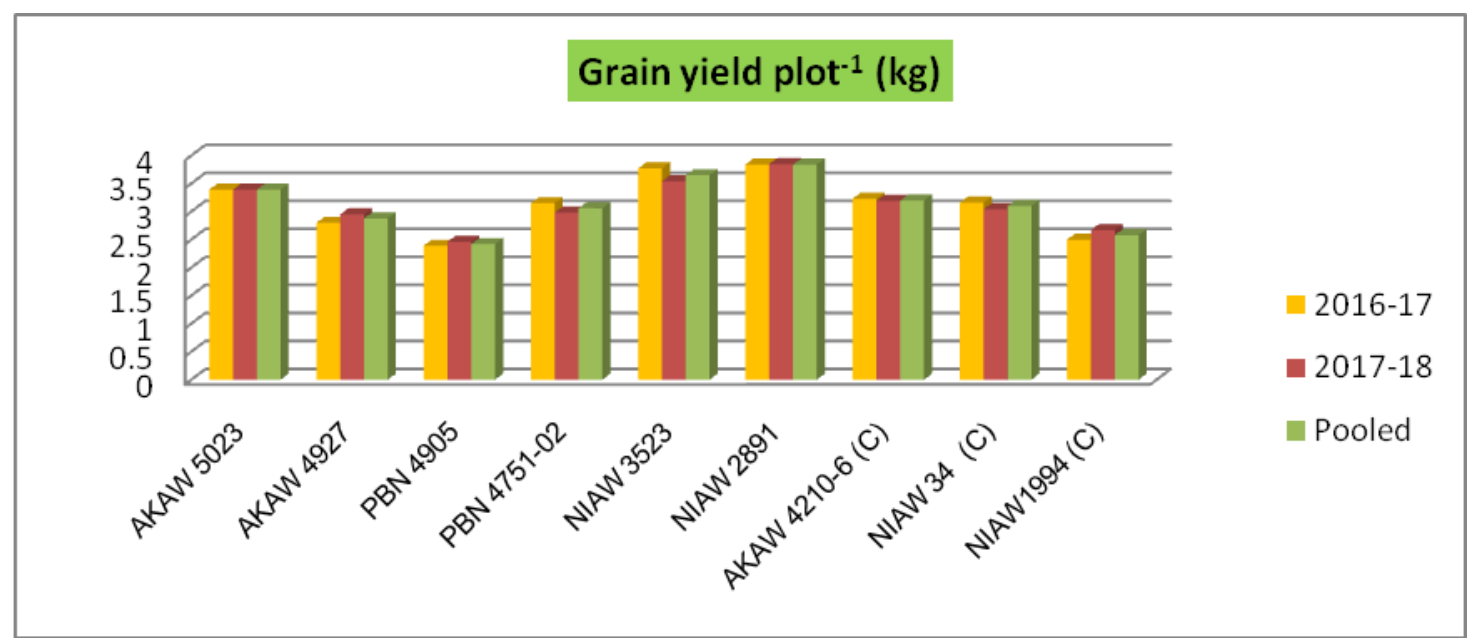


Fig.8 Effect of heat stress on grain yield $\mathrm{ha}^{-1}$ of wheat under heat stress condition

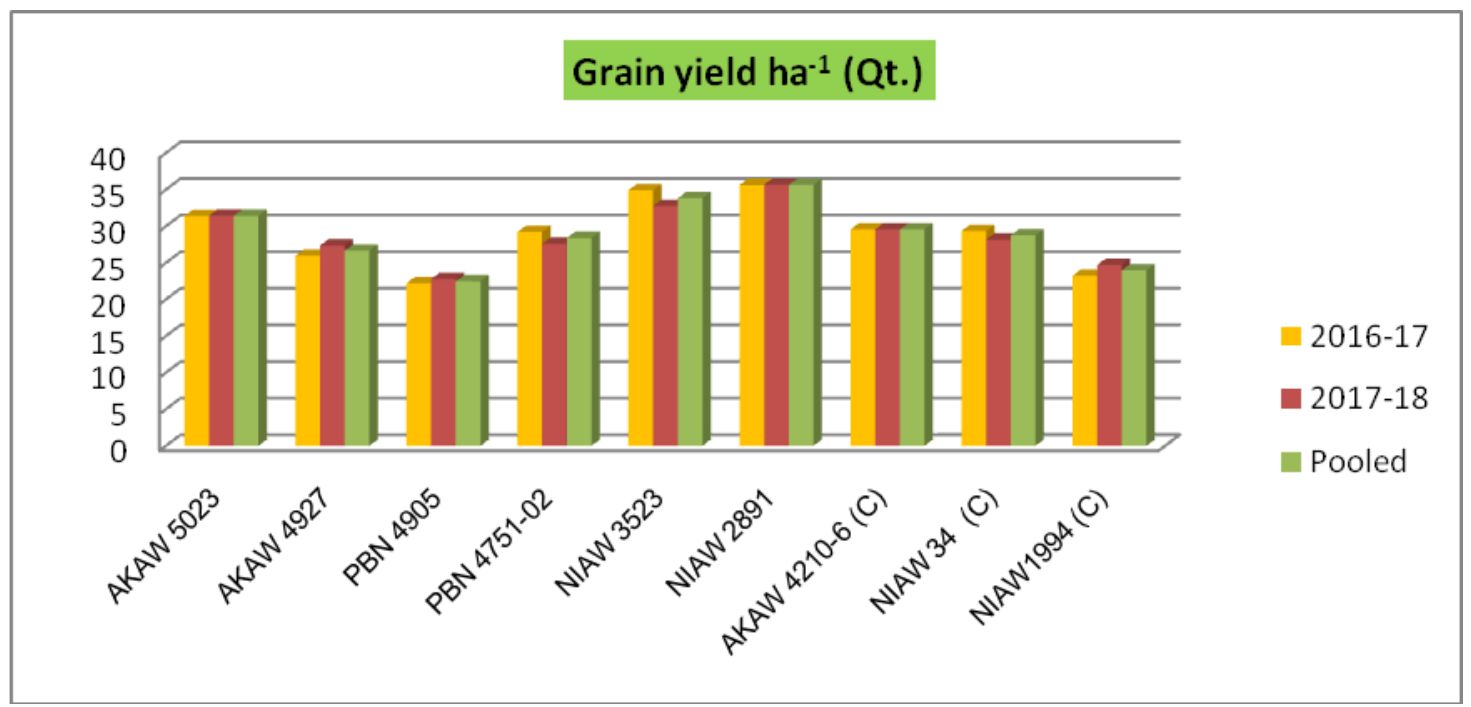

Fig.9 Effect of heat stress on harvest index plant ${ }^{-1}$ of wheat under heat stress condition

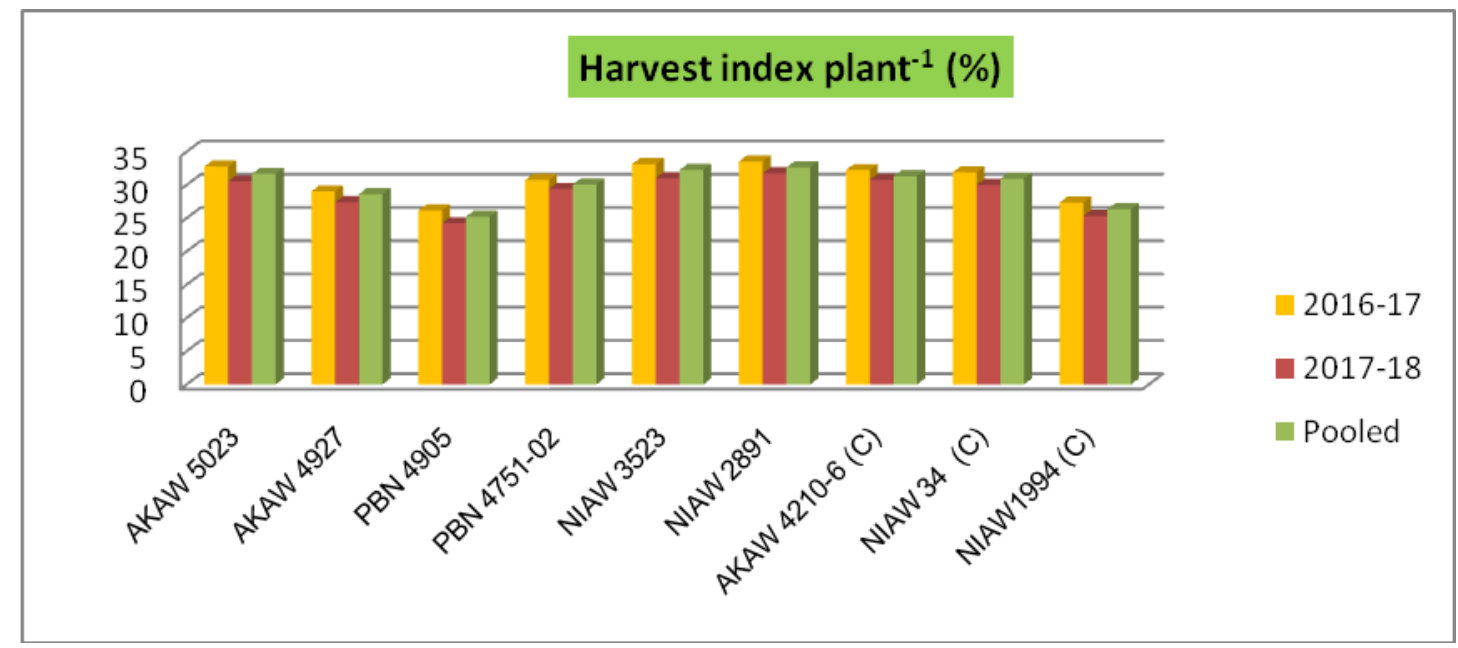

\section{Grain yield ha ${ }^{-1}(q t$.}

Mean pooled data revealed that, top ranking genotype NIAW 2891 has recorded significantly highest grain yield of 35.65 qt ha $^{-1}$ followed by NIAW $3523(33.83$ qt. ha $^{-1}$ ) over superior check AKAW 4210-6 $\left(29.55 \mathrm{ha}^{-1}\right)$ and among all the genotypes tested. Genotypes AKAW $5023 \quad(31.41$ qt. ha ${ }^{-1}$ ) and PBN 4751-02 (28.39 qt. ha ${ }^{-1}$ ) found at par with superior check AKAW 4210-6. However, significantly lowest grain yield was recorded in PBN 4905 and AKAW 4927 (22.48 and 26.66 qt. $^{-1}{ }^{-1}$, respectively) in heat stress condition. The variation in grain yield during both years was due to seasonal effect noted in different genotypes. During rabi 2016-17, after post anthesis sudden increase in ambient temperature by $\left(0.51^{\circ} \mathrm{C}\right)$ when compared with second year rabi 201718, but in rabi 2017-18 minimum temperature was increased by $12.67 \%$ as compared to first year rabi 2016-17 which resulted decreases in soil moisture content and leaf relative water 
content due to evapotransipiration. The reduction in general mean grain yield $\left(\mathrm{ha}^{-1}\right)$ to the extent of $0.11 \%$ in second year when compared with first year might be due to higher temperature observed after anthesis to grain development stage (Fig. 8).

The improvement in grain yield $\mathrm{q} \mathrm{ha}^{-1}$ is to the extent of $20.64 \%$ in high yielding genotype i.e. NIAW 2891 while, reduction in grain yield to extent of $22.91 \%$ in low yielding genotype PBN 4905 over a superior check AKAW 4210-6. Reduction in yield under heat stress condition resulted decreases in metabolic processes and affected the $\mathrm{C}$ : $\mathrm{N}$ ratio in plants, in turn affects flowering, grain set, sex ratio and thereby yield.

\section{Harvest index}

The genotype NIAW 2891 recorded significantly highest harvest index (32.64\%) followed by genotypes NIAW 3523 (32.26 $\%)$, AKAW 5023 (31.66 \%) and PBN 4751-02 (30.07\%) also recorded higher HI and found at par with each other and superior check AKAW 4210-6 (31.32\%). The genotype PBN $4905(25.20 \%)$ and AKAW $4927(28.62 \%)$ recorded significantly lowest harvest index. In this investigation high yielding genotypes viz., NIAW 2891 (32.64\%) and NIAW 3523 (32.26 $\%)$ recorded maximum harvest index. The increase in harvest index in these genotypes is due to increase in grain yield might caused due to well partitioning of photosynthates from vegetative organs (leaves, stem tillers) to grain supported by the findings of Bhagat et al., (2011) (Fig. 9).

\section{Correlation coefficient among yield contributing parameters with yield}

The correlation between yield contributing parameters with grain yield are presented in Table no.1 indicated that the yield contributing parameters viz., rate of grain filling $(0.987 * *), 1000$ grain weight $(0.762 * *)$ and harvest index $(0.719 * *)$ showed positive and significant correlation with grain yield. Similarly, days to maturity with grain growth rate $(0.709 * *)$, rate of grain filling with 1000 grain weigh $(0.753 * *)$ and harvest index and 1000 grain weight with harvest index also showed positive significant correlation.

Laxman et al., (2014) evaluated that, grain yield was positively correlated with grain growth rate and $\mathrm{HI}$ in both timely and late sown varieties. Bhanu et al., (2018) result showed that, 1000 grain weight significant correlation with yield and significant but negative correlation for yield per plot with days to maturity was observed.

Identification of traits associated with heat tolerance of crops is important to increase crop productivity in heat stress under late sown condition. The increase of crop productivity under heat stress could be achieved by manipulating traits associated with high temperature tolerance. Based on the above findings, it is concluded that promising genotypes NIAW 2891, NIAW 3523, AKAW 5023 and check AKAW 4210-6 are more efficient under heat stress condition and hence could be used as sources of heat tolerance in rabi wheat as well as these genotypes should be exploited as parental material in breeding programmed for transferring desired characters in new varieties. Genotypes NIAW 2891, NIAW 3523, AKAW 5023 and AKAW 4210-6 considered as superior for heat stress condition and PBN 4905 and NIAW 1994 noted as heat stress susceptible genotypes.

\section{References}

Acevedo E., Nachit M. and Ferrana GO. (1991). Effects of heat stress on wheat and possible selection tools for use in breeding for tolerance. In: Wheat for the non-traditional warm areas. (Ed. 


\section{D.A. Saunders) pp. 401-420. CIMMYT, Mexico.}

Al-Khatib K. and Paulsen G.M. (1990). Photosynthesis and productivity during high temperature stress of wheat genotypes from major world regions. Crop Science 30:1127- 1132.

Anonymous, 2018. Area, Production and productivity of India and Maharashtra, Director Economics and Statistics Department of Agriculture and Cooperation, 2017-18.

Asana R.D. and Saini AD. (1962). Studies in physiological analysis of yield V. Grain development in wheat relation to temperature, soil moisture and changes with age in the sugar content of the stem and in the photosynthetic surface. Indian Journal of Plant Physiology 5:128-71.

Badruddin M, Saunders D.A., Siddique A.B., Hossain M.A., Ahmed M.O., Rahman M.M. and Parveen S. (1994). Determining yield constraints for wheat production in Bangaldesh. In: Wheat in Heat Stressed Environments; Irrigated, Dry Areas and Rice-Wheat Farming systems (Eds. D. A. Saunders and G. P. Hettel) pp. 265-271. CIMMYT, Mexico.

Bhagat, K. P., R. K. Sairam., P. S. Deshmukh and S.R. Kushwaha. 2011. Biochemical analysis of stem in lodging tolerant and susceptible wheat (Triticum aestivum L.) genotypes under normal and late sown conditions. Indian J. Pl. Physiol. 16(1):68-74.

Bhanu N. A., Arun B., Mishra V. K. 2018. Genetic variability, heritability and correlation study of physiological and yield traits in relation to heat tolerance in wheat (Triticum aestivum L.). Biomed J. Sci. and Tech Res. ISSN: 2574-1241.

Bhatta M.R., Hernandez J.E. and Lates J.S. (1994). Possibilities of selecting wheats with fast grain filling rate for warmer areas. In: Wheat in Heatstressed Environments: Irrigated, June 2007 M. A. Hasan et ah Dry Areas and Rice-Wheat Farming Systems (Eds. D. A. Saunders and G P. Hettel) pp. 375378. CIMMYT, Mexico.

Chinnusamy, V. and Renu Khanna-Chopra, 2009. Physiological and molecular analysis of heat tolerance in diploid, tetraploid and hexaploid wheat species. In Consolidating the productivity gain in wheat- an outlook, IARI, New Delhi, India.

Donald, C. M., 1962, In search of yield. Journal of Australian Institute of Agricultural Sciences, 28:171-178.

G. K. Mc Donald, B. G. Sutton and F. W. Ellison. 1983. "The Effect of Time of Sowing on the Grain Yield of Irrigated Wheat in the Naomi Valley, New South Wales," Australian Journal of Agricultural Research, Vol. 34, No. 3, pp. 229-240.

Gill, K. K., N. Kaur and R. Babuta. 2013. crop growth behaviour and yield characteristics of wheat (Triticum aestivum L.) in two different agroclimatic zones of Punjab. Journal of Agril. Physics. 13(2):126-132.

H. Zhao, T. Dai, Q. Jing, D. Jiang and W. Cao. 2007. "Leaf Senescence and Grain Filling Affects by Post Anthesis High Temperatures in Two Different Wheat Cultivars," Plant Growth Regulation, Vol. 51, No. 2, pp. 149158.

He Z.H. and Rajaram S. (1993). Differential responses of bread wheat characters to high temperature. Euphytica 72: $197-$ 203.

Hulihalli, U. K., Shantveerayya and Mammigatti, U.V. 2016. Effect of planting dates and correlation studies on growth and yield of rabi Sorghum genotypes. Adv. Life Sci., 5 (12): 
5083-5087.

Islam N., Ahmed S.M., Razzaque M.A., Sufian A. and Hossain M.A. (1993). A study on the effect of seeding dates on the yield of wheat varieties. Bangladesh Journal of Agricultural Research 18(1):102-107.

Karmakar S. and Shrestha M.L. (2000). Recent climatic changes in Bangladesh. No. 4. pp. 37-38. SAARC Meteorological Research Centre, Agargaon, Dhaka.

Kumar, A., Sengar R.S., Singh R., Anju Rani, Gyanika Shukla and Girdharwal V. 2015. Screening of heat tolerance wheat germplasm under late seeded condition. JEAB, Vol. 03, No. 04, pp. 206-210.

Kumar, N., Prasad, S., Dwivedi, R., Kumar, A., Yadav, R.K., Singh, M.P. and Yadav, S.S. 2016. Impact of heat stress on yield and yield attributing traits in wheat (Triticum aestivum L.) lines during grain growth development. Int. J. Pure App. Bio. sci. 4(4): 179-184.
Laxman, Singh, V., Solanki, Y. P., Redhu, A. S. 2014. Phenological development, grain growth rate and yield relationship in wheat cultivars under late sown condition. Ind. J. Plant Physiol. (July- September 2014) 19(3): 222-229.

Modheja, A. Naderi, Y. Emam, A. Aynehband, G. H. Normohamadi. 2008. Effects of post-anthesis heat stress and nitrogen levels on grain yield in wheat (Triticum durum and Triticum aestivum) cultivars. Inter J. Plant Pro. 2: 254-267.

Panse, V. G and P. V. Sukhatme, 1967. Statistical method for Agriculture worker, New Delhi ICAR Publication.

Sayed, H.I. and Gadallah, A.M. (1983). Variation in dry matter and grain filling characteristics in wheat cultivars. Field Crops Res., 7: 61 - 71.

Sofield, I., L.T. Evans, M.G. Cook and I. F. Wardlaw 1977. Factors influencing the rate and duration of grain filling in wheat. Austr. J. Pl. Physiol. 4:785-797.

\section{How to cite this article:}

Minakshi R. Neware, D.V. Durge and Potdukhe, N.R. 2019. Performance of Wheat Genotypes under Late Sown Heat Stress Condition. Int.J.Curr.Microbiol.App.Sci. 8(11): 1630-1640. doi: https://doi.org/10.20546/ijcmas.2019.811.188 